\title{
Apoptotic cell death and cytokine dysregulation in human immunodeficiency virus infection: pivotal factors in disease progression
}

\author{
Mario Clerici ${ }^{1,3}$, Apurva Sarin ${ }^{2}$, Pierre A. Henkart ${ }^{2}$ and \\ Gene M. Shearer ${ }^{2}$ \\ 1 Cattedra di Immunologia, Universita' degli Studi di Milano, Padiglione L.I.T.A., \\ Ospedale L. Sacco, Via G.B. Grassi, 74, 20154, Milano, Italy \\ ${ }^{2}$ Experimental Immunology Branch, NCI, NIH, Bethesda, MD, 20892, USA \\ 3 corresponding author: Mario Clerici, MD, Cattedra di Immunologia, Università \\ degli Studi di Milano, Via Venezian, 1, 20133 Milano, Italy. tel: 39-2-3821-03- \\ 54; fax: 39-2-3821-0350; e-mail: mago@imiucca. csi.unimi.it
}

Received 12.6.97; Revised 4.9.97 accepted 11.9.97

Edited by M. Piacentini

\begin{abstract}
The progressive loss of CD4 T lymphocyte is patognomonic of Human Immunodeficiency Virus (HIV) infection and results in immunodeficiency and the appearance of acquired immunodeficiency syndrome (AIDS)-defining pathologies. Although a percentage of CD4 T lymphocytes is destroyed directly by HIV infection, a much higher proportion of lymphocytes remains uninfected and therefore must be destroyed by mechanisms not directly involving viral infection. One such mechanism is apoptotic T cell death (ATCD). ATCD in HIV infection has been shown to be: 1) secondary to cross-linking of CD4 by viral proteins; 2) mediated by both APO-1/Fas and lymphotoxin (LT); and 3) differentially modulated by type 1 and type 2 cytokines. We will briefly analyze the experimental evidences suggesting that ATCD contributes significantly to the immunopathogenesis of HIV/AIDS via depletion of $\mathrm{CD}^{+} \mathrm{T}$ cells.
\end{abstract}

Keywords: apoptosis; programmed cell death; HIV; AIDS; immunology; cytokines; T lymphocytes

\begin{abstract}
Abbreviations: HIV, human immunodeficiency virus; AIDS, acquired immunodeficiency syndrome; ATCD, apoptotic T cell death; LT, lymphotoxin; SIV, simian immunodeficiency virus; CTL, cytotoxic T cell-mediated; TNF, tumour necrosis factor; IL, interleukin; IFNg, interferon gamma; TH, T helper; FasL, Fas ligand; SAPO-1/Fas, soluble form of APO-1/Fas; APC, antigen presenting cells; MLR, mixed lymphocyte reaction; PHA, phytohaemagglutinin; CEL, cell antiviral factor; TcR, T cell receptor; $P C D$, programmed cell death
\end{abstract}

\section{Introduction}

Apoptotic T cell death (ATCD) is an active process in which chromatin condensation and DNA fragmentation is asso- ciated with the death of T lymphocyte and other cell types (rev in Ameisen, 1994). ATCD has essential physiological roles in embriogenesis (rev. in Ellis et al, 1991; Cohen et al, 1992) including the regulation of positive and negative selection of immature thymocytes (rev. in Ransdell and Fowlkes, 1990), thus influencing and shaping the final $T$ cell repertoire. In human immunodeficiency virus (HIV) infection, progression of disease classically results from the destruction of $\mathrm{CD}^{+}{ }^{+} \mathrm{T}$ lymphocytes. Despite years of investigation, the mechanism(s) responsible for the death of this subset of cells has not yet been completely elucidated. Different mechanisms have classically been suggested to be involved in the depletion of CD4 lymphocytes. Thus, CD4 ${ }^{+} \mathrm{T}$ cell destruction can be provoked by direct viral infection of target cells resulting in: (1) HIV budding from infected cells with subsequent creation of pores and osmotic death; (2) generation of non-vital syncytia between HIV-infected and uninfected cells; and (3) toxic effects secondary to the presence of proviral DNA in the cytoplasm of host cells (rev. in Weiss, 1993; Levy 1993). Recently, elegant studies have highlighted the role that accelerated and extensive viral replication has in the destruction of CD4 ${ }^{+}$lymphocytes (Wei et al, 1995; Ho et al, 1995). Thus, it was estimated that more than $10^{9}$ new viral particles are formed every day in HIV infected individuals, and that approximately $5 \%$ of the circulating pool of CD4 T lymphocytes is destroyed and replenished daily as a consequence of such massive turn over (Wei et al, 1995; Ho et al, 1995). Even more recently, the half life of simian immunodeficiency virus (SIV) in macaques continuously infused with virus was calculated to be equal to 20-30 min (Ho et al, 1997). Despite raising some questions about the artificiality of the experimental model chosen, these data emphasize the important contribution of direct virus killing in HIV and SIV retroviral infections. Predictions from these mathematical models postulated that therapy that reduces HIV viral load to undetectable values would result in a quantitative reconstitution of the circulating pool of CD4 T lymphocytes (Wei et al, 1995; Ho et al, 1995). Despite the availability of such therapy, capable of inducing powerful and long-lasting reductions in HIV viral load, these predictions were not fulfilled (see further), raising questions about the role that other factors might play in the depletion of CD4 lymphocytes seen in disease progression.

Apoptotic cell death plays a fundamental role in $\mathrm{CD}^{+} \mathrm{T}$ cell depletion in HIV infection; experimental evidences

It is unlikely that a cytopathic effect of HIV on infected cells can account for the depletion of $\mathrm{CD}^{+} \mathrm{T}$ cells that is 
characteristic of HIV infection. Infact: (1) only a minority of T lymphocytes contains HIV genetic material; and (2) the percentage of CD4 loss attributable to direct HIV infection was recently evaluated to be roughly $10 \%$ of the circulating pool even in the most advanced phases of the disease (Haase, 1996). Additionally, the increases in the number of circulating CD4 in patients undergoing antiretroviral therapies that include the use of protease inhibitors, and in whom HIV viral load is virtually reduced to zero, are only partial (Kelleher et al, 1996; Connors et al, 1997). Additional discrepancies are observed in patients treated with these therapies. Thus: (1) the persistent suppression of HIV viral load, often under the limit of detectability, is associated with increases in $\mathrm{CD}^{+} \mathrm{T}$ cell counts that are only observed in the first weeks or months of therapy (Kelleher et al, 1996; Connors et al, 1997); and (2) antiretroviral therapies are not associated with modification of in vitro susceptibility of peripheral blood mononuclear cells to apoptosis. These data suggest that mathematical models predicting viral replication to be the only factor responsible for CD4 depletion and disease progression have not taken in consideration other mechanisms that could be responsible for such processes.

Non-virally mediated mechanisms that have been known to be involved in the destruction of $\mathrm{CD}^{+}{ }^{+} \mathrm{T}$ cells in HIV infection include lysis of lymphocytes via antibody dependent complement cytotoxicity, and cytotoxic $T$ cellmediated (CTL) destruction of targets presenting either viral products or HLA alloantigens on their surface. These mechanisms have been reviewed elsewhere by others (Levy 1993; Zinkernagel and Hengartner, 1994) and will not be covered in this article. An alternate mechanism that could lead to CD4 depletion was recently presented by Wolthers and colleagues (1996). These authors have analyzed telomere length in CD4 and CD8 lymphocyte of HIV-infected individuals and have observed that the telomere length of the terminal restriction fragment was reduced in CD8+ but not in CD4+ $\mathrm{T}$ cells of HIVseropositive individuals. The authors have thus put forward the hypothesis that depletion of CD4 T cells might be secondary not to an increased death of mature $T$ cells, but rather to an interference of CD4 $\mathrm{T}$ cell renewal from progenitors. In this review we will nevertheless focus on the pathogenetic role of ATCD in the progression of HIV infection.

T lymphocytes of HIV infected patients were observed to undergo apoptosis without stimulation (Laurent-Crawfors et al, 1991; Gougeon et al, 1991; Ameisen and Capron, 1991; Meeyard et al, 1992) or when stimulated with antigens or mitogens (Groux et al., 1992; Oyazu et al, 1993; Banda et al, 1993; Clerici et al, 1994) and in vitro infection of HIVseronegative lymphocytes induces apoptosis (Terai et al, 1991). Even more important, apoptotic death of HIV infected lymphocytes was shown to be dominant in uninfected, bystander cells and not in productively infected cells, both in the peripheral blood and in lymph nodes of HIV-seropositive individuals (Finkel et al, 1995; Piazza et al, 1997). Apoptotic death in HIV infection was subsequently established to be associated with at least two different components of the nerve growth factor/tumor necrosis factor (TNF) receptor family: lymphotoxin (LT)
(Clerici et al, 1996) and APO-1/Fas (Fas) (Katsikis et al, 1995; Silvestris et al, 1996; Estaquier et al, 1996; Sloan et al, 1997). ATCD was also suggested to be reduced by soluble APO-1/Fas (sAPO-1/Fas), a soluble form of APO-1/ Fas that prevents engagement of membrane-bound Fas and thus reduces Fas-mediated apoptosis (Cheng et al, 1994). Finally, susceptibility of lymphocytes to ATCD in HIV infection was observed to be differentially regulated by interleukin (IL)-2; interferon gamma (IFNg) and IL-12 (type 1 cytokines) as opposed to IL-4 and IL-10 (type 2 cytokines). Thus, type 1 cytokines were shown to have a protective role in preventing ATCD whereas type 2 cytokines were not protective, and augmented ATCD of peripheral lymphocytes in some HIV infected individuals (Clerici et al, 1994, 1996; Radrizzani et al, 1996; Estaquier et al, 1996). The potential relevance of ATCD in disease progression was illustrated by the following observations: (1) the percentage of lymphocyte spontaneously undergoing apoptosis is directly proportional to the reduction in $\mathrm{CD}^{+}{ }^{+}$cell counts (Gougeon et al, 1996); (2) susceptibility of antigen- and mitogen-stimulated peripheral lymphocyte to apoptosis increases with disease progression (Gougeon et al, 1996); (3) serum concentration of LT and SAPO-1/Fas are predictors of disease progression independent of HIV viral load (Medrano et al, 1997); and (4) apoptosis is not present in HIV infected chimpanzees in whom $\mathrm{CD}^{+} \mathrm{T}$ cell depletion, alteration of $\mathrm{T}$ helper $(\mathrm{TH})$ cell function, and the development of AIDS are not observed (Heeney et al, 1993; Gougeon et al, 1993, 1996), but is observed in macaques infected with pathogenic strains of SIV (Estaquier et al., 1994).

\section{The Fas/Fas ligand system and apoptosis in HIV infection}

Activation of Fas by it ligand (FasL) can trigger $T$ cell proliferation and cytokine production or can induce apoptosis in susceptible cells (Yonehara et al, 1989; Ito et al, 1991; Alderson et al, 1995; Dhein et al, 1995; Force et al, 1995; Ju et al, 1995; Nagata and Golstein, 1995). This system is finely regulated as it was recently shown that a soluble form of Fas (SAPO-1/Fas) can prevent the interaction between Fas and FasL thus reducing apoptosis (Cheng et al, 1994).

Because different pathologic conditions are associated with reduction in the serum concentration of SAPO-1/Fas (Tanaka et al, 1996), this is an approach by which Fasdependent ATCD can be modulated. Surface expression of Fas was found to be increased on lymphocytes of HIVinfected individuals (Debatin et al, 1994; McCloskey et al, 1995; Silvestris et al, 1996). Additionally, the interaction of Fas with its ligand in HIV-infected cells provokes ATCD in a much higher percentage of lymphocyte (Katsikis et al, 1995; Sloan et al, 1997). Thus, lymphocytes of HIVseropositive individuals express Fas in higher quantities and are more prone to undergo ATCD upon ligation of this receptor. Recent data suggest that activated CD4 T lymphocytes can kill CD8 effector T cells via Fas/FasL mediated apoptosis (Piazza et al, 1997). If these data can be extended to the setting of HIV infection, it is possible that such a mechanism could explain selective killing of 
Table 1 Experimental evidences (in vitro) suggesting a role for alterations of the Fas/Fas ligand (FasL), soluble APO-1/Fas (sAPO-1/Fas) system in HIV infection

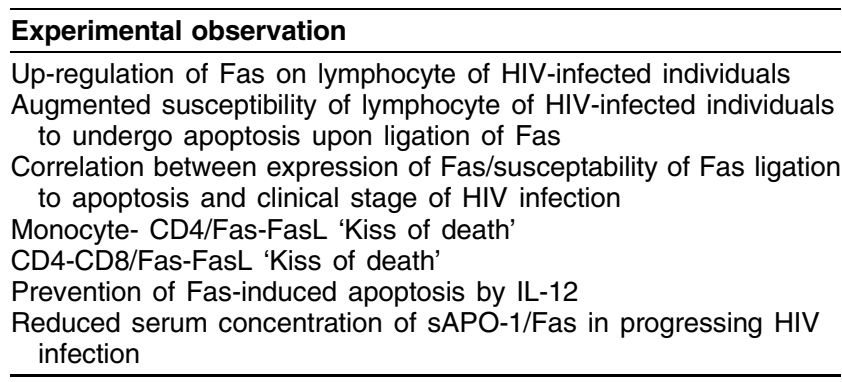

HIV-specific CTL, allowing viral mutants to escape immune recognition and control. Another recent set of data shows that up-regulation of Fas on monocytes is observed in HIV infection, and postulates the augmented expression of Fas on these cells to be responsible for the destruction of uninfected CD4 $\mathrm{T}$ lymphocyte subsequent to antigenic presentation and Fas interaction, via a classical 'kiss of death' mechanism (Badley et al, 1997). Different experimental findings support a role for the quantitative/qualitative alterations of the Fas/FasL system in the progression of HIV infection to AIDS (Table 1).

In summary: (1) surface expression of Fas is augmented in disease progression and individuals with AIDS and opportunistic infections express significantly more Fas than asymptomatic patients (Debatin et al, 1994; McCloskey et al, 1995; Sivestrisn et al, 1996); (2) ATCD induced by engagement of Fas on the surface of CD4 lymphocyte is higher in symptomatic than in asymptomatic HIV-infected individuals (Katsikis et al, 1995; Sloan et al, 1997); (3) the magnitude of anti-Fas-induced ATCD inversely correlates with absolute CD4 cell counts (Katsikis et al, 1995); and (4) IL-12 (the generation of which decreases in the progression of HIV infection) prevents Fas-mediated apoptosis of lymphocyte of HIV-seropositive individuals (Radrizzani et al, 1995). A different set of data further supports the importance of Fas/FasL in the pathogenesis of HIV infection. Low serum concentrations of sAPO-1/Fas were recently shown to have a strong independent predictive power for progression to AIDS in a multivariate conditional logistic regression model that included among other variables, HIV viral load at entry (Medrano et al, 1997). Thus, complex alteration of the Fas/FasL/sAPO-1/Fas system are present in HIV infection and are likely to be involved in $\mathrm{CD}^{+} \mathrm{T}$ cell depletion and in the progression of HIV infection.

\section{Cell mediated immunity is defective in HIV infection}

The progression of HIV infection is also characterized by a complex dysregulation in the function of TH cells (Lane et al, 1985; Giorgi et al, 1987; Miedema et al, 1988; Clerici et al, 1989). At least two different types of functional defects have been observed in HIV-infected individuals. Thus, defects in both $\mathrm{TH}$-antigen presenting cells (APC) interactions and in cytokine production were described. The defects associated with the interaction between $\mathrm{TH}$ and APC are multiple and sequential, and can be summarized as follows: (1) TH defects (analyzed as the ability of TH lymphocytes to proliferate and to secrete IL-2) to soluble antigens appear early in the disease (Clerici et al, 1989). Because soluble antigens need to be processed and presented on the surface of autologous APC in association with $\mathrm{MHC}$ class II to CD4 T lymphocyte (rev. in Naor, 1992), this is the most sensitive index of dysfuction of these lymphocyte. That is defect is not secondary to an impairment in the capacity of APC to process/present antigenic peptides was shown by experiments in which soluble antigen-sensitised APC from HIV-infected monozygotic twins were able to stimulate CD4 TH of the HIVuninfected twins (Clerici et al, 1990; Blauvelt et al, 1995); (2) Defects in $\mathrm{TH}$ function in response to stimulation with allogeneic lymphocytes in a mixed lymphocyte reaction (MLR) appear next, in patients in whom the ability to respond to soluble antigens was lost earlier (Clerici et al, 1989). Because both CD4 and CD8 T lymphocytes are stimulated in MLR and both autologous and heterologous APC can stimulate lymphocytes (Via et al, 1990), this TH defect is less specific for CD4 TH lymphocytes; (3) PHA-stimulated proliferation and IL-2 production can become defective in HIVseropositive individuals in whom $\mathrm{TH}$ defects to soluble antigens and alloantigens are observed. Because both CD4 and CD8 T cells are stimulated by PHA and because the ability of this mitogen to stimulate lymphocyte is only marginally dependent on APC, the inability to respond to mitogens is an index of a profound and massive impairment in TH function in HIV infected patients (Clerici et al, 1989). These functional defects are: (1) observed in the majority of HIVseropositive individual even during the phase of clinical latency; (2) sequential (i.e. loss of response to soluble antigens preceeds loss of response to alloantigens which preceeds the inability to respond to PHA); and (3) independent of changes in CD4 cell counts (Clerici et al, 1989). From a practical standpoint, these functional defects were shown to be predictive for three major clinical endpoints: (1) destruction of CD4 T lymphocytes and disease progression (Lucey et al, 1991); (2) time to AIDS (Dolan et al, 1995); and (3) time to death (Dolan et al, 1995). Thus, a recent publication analyzed time to AIDS diagnosis and survival time in a group of HIV seropositive individuals and observed significantly longer disease-free time and survival in those individuals in whom no in vitro TH defects to either soluble antigens, alloantigens, or PHA were detected at the time of entry into the study (Dolan et al, 1995).

More recently, alterations in cytokine production were reported to be associated with the progression of HIV infection (rev. in Clerici and Shearer, 1993, 1994a; Klein et al, 1997). A series of reports analyzed the production of two functionally distinct families of cytokines: type 1 cytokines (IL-2; IFNg; IL-12; IL-15) that are mainly aimed at the activation of cell mediated immunity and the destruction of intracellular parasites; and type 2 cytokines (IL-4; IL-5; IL-6; IL-10; IL-13), more targeted toward the activation of $B$ lymphocyte and protection against extracellular microorganisms. A progressive decline in type 1 cytokines and a parallel increase in the generation of some type 2 cytokines, and a subsequent shift away from cell mediated 
immunity and in favor of humoral immunity were suggested to characterize the course of HIV infection (rev. in Clerici and Shearer, 1993; 1994a; Klein et al, 1997). This hypothesis was confirmed by different lines of investigation. To summarize: (1) $\mathrm{IL}-2$ and $\mathrm{IL}-12$ production are reduced in HIV-seropositive patients and both IL-12 and IL15 restore in vitro defective soluble antigen-stimulated proliferation of TH cells from HIV-infected individuals (see above) (rev. in Clerici and Shearer, 1993; 1994a; Seder et al, 1995); (2) increased IL-4, IL-6, IL-10, and/or IL-13 production are present in HIV infection, and anti-IL-4 as well as anti-IL-10 neutralizing antibodies increase antigenstimulated proliferation of HIV-infected lymphocyte (rev. in Clerici and Shearer, 1993; 1994a); (3) a strong production of IL-2 and IFNg and weak production of IL-4 and IL-10 are observed in both adult and pediatric long-term nonprogressing HIV seropositive individuals, whereas a specular cytokine pattern is detected in patients who progress towards AIDS (Vigano' et al, 1995; Clerici et al, 1996); (4) the ability to respond to common antigens in vivo in a delayed type hypersensitivity reaction, a classical type 1 cytokines-driven reaction, is lost in, and predictive for, disease progression (Blatt et al, 1993; Dolan et al, 1995); (5) in vivo, the presence of hematological parameters associated with a type 2 cytokine production such as IL-4 driven hyper-IgE (Lucey et al, 1991; Israel-Biet et al, 1993) and IL-5 driven hypereosinophilia (Fleury-Feith et al, 1992; Smith et al, 1994, Caterino-de-Araujo, 1994) are unfavorable prognostic factors and are clinically associated with rapid disease progression.

Additionally, it was shown that cytokine impairment and defects in $\mathrm{TH}$ cell function are not present in HIV-infected chimpanzees, in which infection and seroconversion are not accompanied by disease progression (Heeney et al, 1993; Gougeon et al, 1993, 1996). More recent results from experiments in which macaques were infected with either normally pathogenic SIV strains or with non-pathogenic Nef-deleted strains of SIV showed infection with the latter strains of virus to be associated with the preferential development of a type 1 cytokine pattern, and this pattern to be predictive of disease outcome (Zou et al, 1997). Finally, the C-C chemokines MIP- $1 \alpha$, MIP- $1 \beta$ and RANTES as well as a CD8-secreted cell antiviral factor (CAF), were observed to prevent HIV infection of target lymphocyte in vitro (Walker et al, 1986; Cocchi et al, 1995). The syntesis of both families of soluble antiviral factors was shown to be associated with a type 1 immune response and the generation of IL-2 and IFG $\gamma$, but not of IL-4, IL-5 or IL-10 (rev. in Levy et al, 1996).

\section{Cytokines influence susceptibility of lymphocytes to ATCD in HIV infection}

In an attempt to correlate seemingly independent observations, the possible association between HIV disease progression, impairment of cytokine production, and destruction of $\mathrm{CD}^{+}{ }^{+} \mathrm{T}$ lymphocytes (ATCD) was analyzed by a number of investigators. Background for this line of research stems from results showing that cytokines can influence $T$ cell receptor (TcR) programmed cell death (PCD), as IL-2 was capable of blocking $\alpha$-CD3- induced PCD of both CD4 ${ }^{+} \mathrm{CD} 8^{-}$ and $\mathrm{CD}^{-}{ }^{-} \mathrm{CD}^{+}$resting thymocytes (Nieto et al, 1990; Groux et al, 1993). Additionally, other researchers have shown that exogenously supplemented IL-2 results in Bcl-2-mediated increased survival of memory T cells, and removal of IL-2 from activated $\mathrm{T}$ cells results in down-modulation of $\mathrm{Bcl}-2$ and apoptosis. In summary: (1) after antigen recognition via their $T$ cell receptor (TcR) normal $T$ cells, instead of classically becoming activated to proliferate can undergo PCD (rev. in Golstein et al, 1991, Cohen et al, 1992, Ameisen, 1994); (2) lymphocytes of HIV infected patients are particularly susceptible to TcR-induced ATCD (rev. in Ameisen, 1994); (3) loss of type 1 cytokine and increase in type 2 cytokine are observed in HIV infection (rev. in Clerici and Shearer, 1993). Results of these investigations have shown that in vitro antigen- and mitogen-stimulated ATCD of lymphocytes in HIV-infected individuals is influenced by cytokines. Thus, the addition of exogenous type- $1 \mathrm{IFNg}, \mathrm{IL}-2$, and IL-12 blocks $T$ lymphocyte ATCD (Clerici et al, 1994, 1996; Radrizzani et al, 1996; Estaquier et al, 1996). In contrast, the type-2 lymphokines IL-4 and IL-10, have either no effect or enhance in vitro T cell ATCD (Clerici et al, 1994, 1996; Estaquier et al, 1996). Additionally, antigen- and mitogen-stimulated ATCD can be inhibited by antibodies against IL- 4 and IL-10, and enhanced by anti-IL-12 (Clerici et al, 1994, 1996; Estaquier et al, 1996). In particular, it was shown that: (1) IL-12 inhibits apoptosis induced in human Th1 clones by three different methods: gp120-CD4 cross-linking, CD3-TcR activation, and IL-2 deprivation (Radrizzani et al, 1996); (2) IL-12 as well as neutralizing antibodies to IL-4 and IL-10 prevent activationinduced and Fas-mediated apoptosis of $\mathrm{CD}^{+} \mathrm{T}$ lymphocytes of HIV-infected patients (Estaquier et al, 1996); and (3) in vitro stimulation of T cells via the TcR induces extensive apoptotic death of both the CD4 and CD8 subsets (Clerici et al, 1994), whereas antigen-stimulated apoptotic death is limited to CD4 lymphocyte of HIV-infected individuals (Clerici et al, 1996). Nevertheless, ATCD is blocked in both cases by type 1 , but not by type 2 cytokines (Clerici et al, 1994, 1996); and (4) type 1 but not type 2 cytokines can prevent LT-mediated ATCD of antigen-stimulated CD4 lymphocyte of HIV-infected indivi-

Table 2 Effects of type 1 and type 2 cytokines on susceptibility to apoptosis of peripheral lymphocyte in HIV infection. Experiments were performed in vitro

\begin{tabular}{lc}
\hline Cytokine & $\begin{array}{l}\text { Biologic effect on apoptosis } \\
\text { of peripheral lymphocytes }\end{array}$ \\
\hline $\begin{array}{l}\text { Type 1 cytokines } \\
\text { Interleukin-2 } \\
\text { Interferon gamma } \\
\text { Interleukin-12 }\end{array}$ & $\begin{array}{l}\text { Reduction } \\
\text { Reduction }\end{array}$ \\
$\begin{array}{l}\text { Type 2 cytokines } \\
\text { Interleukin-4 }\end{array}$ & Reduction \\
Interleukin-10 & No effect or augmentation \\
Neutralizing antibodies to type 1 cytokines \\
anti-interleukin-2 \\
anti-interleukin-12 & No effect or augmentation \\
Neutralizing antibodies to type 2 cytokines \\
anti-interleukin-4 \\
anti-interleukin-10
\end{tabular}


duals (Clerici et al, 1996). These data indicate that cytokines are able to modulate apoptosis mediated by the three major known mechanisms: Bcl-2; Fas; and LT (Table 2).

From the evidences presented above, it appears that ATCD is a major contributor to the destruction of $\mathrm{CD}^{+} \mathrm{T}$ lymphocytes in HIV disease via mechanisms independent of actual infection of the target cells, and that the profound dysregulation of the immune response present in this infection influences the phenomenon. But, how can HIV uninfected lymphocyte be sensitised to undergo ATCD? The finding that stimulation with CD4-dependent antigens such as gp120 peptides increase ATCD in the CD4 but not in the CD8 subset, suggests in vivo antigenic stimulation through infections to initiate extensive apoptotic death that is selective for CD4 T cells specific for antigens other than those used to initiate the death signal. Exposure of CD4 T

\section{Apoptotic model of immunopathogenesis:}

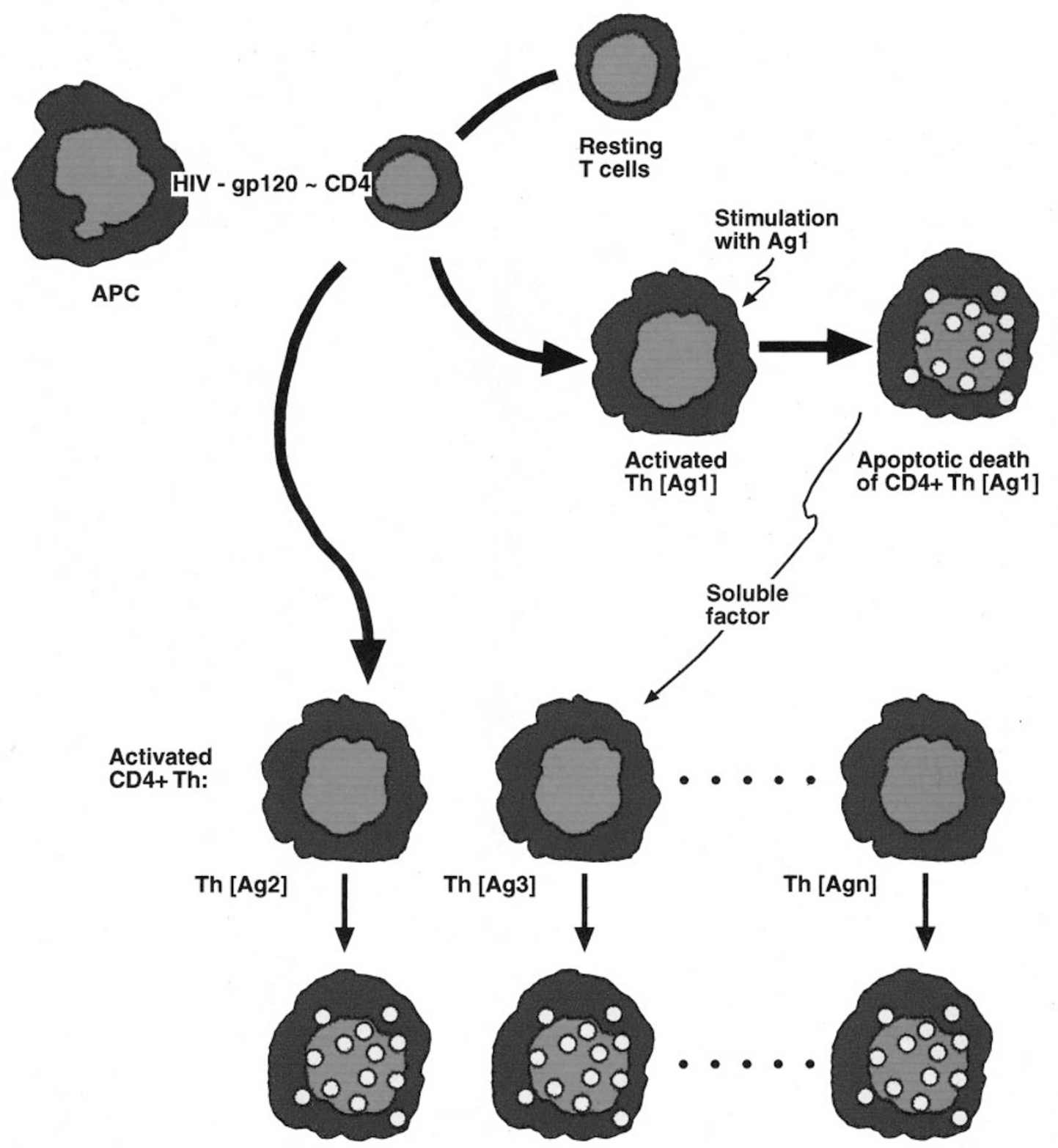

<-- Apoptotic death of CD4+ Th[Ag2, Ag3, ..., Agn] -->

Figure 1 Model of extensive T cell activation via gp120 (presented by APC) interaction with CD4 on T lymphocytes. Activated T cells of different specificities are then susceptible to ATCD that is effected by LT (or Fas) released by antigen stimulation (with $\mathrm{Ag} 1$ ) of an activated T cell clone 
cells to HIV or HIV products could activate or sensitize T cells for a secondary ATCD - inducing stimulus, resulting in extensive $T$ cell death (Figure 1). In this context, gp120 protein crosslinked to uninfected CD4 T cells followed by $T$ cell receptor signaling has been reported to induce apoptotic $\mathrm{T}$ cell death, and Tat was similarly shown to sensitize uninfected CD4 $\mathrm{T}$ cells for antigen-stimulated apoptotic death (extremely interesting in this regard is the observation by Ehret et al., 1996, showing that T cells form chimpanzees resist Tat-induced apoptosis). More recently (see above) interaction between APC-expressing Fas and uninfected $\mathrm{CD}^{+} \mathrm{T}$ cells was shown to deliver a 'kiss of death' to such cells. These non-infectious interactions between CD4 T cells and HIV or its products are likely to contribute appreciably to the depletion of CD4 T cells in HIV disease, without the need for infection of such cells. This mechanism would result in pan-depletion of activated T cells expressing a broad spectrum of antigen specificities. This depletion was shown to be reduced by cytokines such as IL-2, IL-12 and IFNg, and enhanced by IL-4 and IL-10. The observation that type 1 cytokines (protective against ATCD) are reduced, whereas type 2 cytokines (non protective against ATCD) are augmented in disease progression, accounts for the continuous and massive destruction of CD4 lymphocyte and, ultimately, to the appearance of AIDS. This model is shown in Figure 1.

\section{Conclusions}

Increased susceptibility of peripheral lymphocytes to ATCD characterizes the progression of HIV infection to AIDS. ATCD in HIV infection is dominant in virus-uninfected cells and appears to be mediated by at least two pathways, the first dependent of Fas and the second on LT. Progression of HIV disease to AIDS is also accompanied by alterations in the imbalance between the production of type 1 and type 2 cytokines. These apparently unrelated observations were linked by recent reports showing that the tendency of $\mathrm{CD} 4^{+} \mathrm{T}$ lymphocytes of HIV infected individuals to undergo apoptosis is differently modulated by type 1 cytokines (protective against both Fas- and LT-mediated apoptosis) that decline, and type 2 cytokines (not protective and possibly enhancing ATCD) that augment in in disease progression. The recent reports of consistent increases in CD4 counts in patients receiving intermittent IL-2 therapy (Kovacs et al., 1995) support these experimental findings and reinforce the suggestion that rational end efficient drug therapy in HIV infection would possibly combine three distinct classes of drugs, namely antiretrovirals; immunomodulants; and agents targetted at preventing apoptosis of uninfected cells.

\section{Acknowledgements}

This paper was supported by grants from Instituto Superiore di Sanita' 'IX Progetto AIDS 1996'.

\section{References}

Ameisen JC and Capron A (1991) Cell dysfunction and depletion in AIDS: the programmed cell death hypothesis. Immunol. Today 12: 102-106
Ameisen J-C (1994) Programmed cell death (apoptosis) and cell survival regulation: relevance to AIDS and cancer. AIDS 8: 1197-1213

Alderson MR, Tough TW, Davis-Smith T, Braddy S, Falk B, Schooley KA Goodwin RG, Smith CA, Ramsdell F and Lynch DH (1995) Fas ligand mediates activation-induced cell death in human $\mathrm{T}$ cell lymphocytes. J. Exp. Med. 181: $71-77$

Badley AD, Dockrell D, Simpson M, Schut R, Lynch DH, Leibson P and Paya CV (1997) Macrophage-dependent apoptosis of CD4+ T lymphocytes from HIV-infected individuals is mediated by FasL and TNF. J. Exp. Med. 185: $55-64$

Banda NK, Bernier J, Kurahara DK, Kurrle R, Hadgwood N, Sekaly R-P and Finkel TH (1993) Crosslinking CD4 by HIV gp120 primes T cells for activation-induced apoptosis. J. Exp. Med. 176: 1099-1106

Blauvelt A, Clerici M, Lucey DL, Shearer GM and Katz S (1995) Functional studies of epidermal Langherans cells and blood monocytes in human immunodeficiency virus-infected individuals. J. Immunol. 154: 3506-3515

Blatt SP, Hendrix CW, Butzin CA, Lucey DR and Boswell RN (1993) Delayed type hypersensitivity skin testing predicts progression to AIDS in HIV-infected patients. Ann. Int. Med. 119: 177-184

BrunnerT, Mogill R, LaFace D, Yoo NJ, Mahboul A, Echeverri F, Martin SJ, Force WR, Lynch DH, Ware CF and Green DR (1995) Cell autonomous Fas (CD95)/FasL interaction mediates activation-induced apoptosis in T cell hybridomas. Nature 373: $441-444$

Caterino-de-Araujo A (1994) HIV-1 infection and eosinophilia. Immunol. Today 15 498-499

Cheng J, Zhou T, Liu C. Shapiro JP, Brauer MJ, Kiefer MC, Barr PJ and Muonz JD (1994) Protection from Fas-mediated apoptosis by a soluble form of the Fas molecule. Science 263: 1759-1762

Clerici M, Stocks NI, Zajac RA, Boswell RN, Lucey DR, Via CS and Shearer GM (1989) Detection of three distinct patterns of $T$ helper cell dysfunction in asymptomatic, human immunodeficiency virus-seropositive patients. Independence of CD4+ cell numbers and clinical staging. J. Clin. Invest. 84 : $1892-1899$

Clerici M, Stocks NI, Zajac RA, Boswell RN and Shearer GM (1990) Accessory cell function in asymptomatic, human immunodeficiency virus infected patients. Clin. Immunol. Immunopathol. 58: 168-173

Clerici Mand Shearer GM (1993)A TH1 - > TH2 switch is a critical step in the etiology of HIV infection. Immunol. Today 14: 107-111

Clerici M and Shearer GM (1994a) The TH1/TH2 hypothesis of HIV infection: new insights. Immunol. Today 15: 575-581

Clerici M, Sarin A, Coffman RL, Wynn TA, BlattSP, Hendrix CW, Wolf SF, Shearer GM and Henkart PA (1994b) Type1/type2 cytokine modulation of T cell programmed cell death as a model for HIV pathogenesis. Proc. Natl. Acad. Sci. (USA) 91: $11811-11815$

Clerici M, Sarin A, Berzofsky JA, Landay AL, Kessler HA, Hendrix CW, Blatt SP Henkart PA and Shearer GM (1996a) Antigen-stimulated CD4+ T cell death in HIV infection is selective for CD4+T cells, regulated by cytokines and effected by lymphotoxin. AIDS 10: 603-611

Clerici M, Balotta C, Meroni L, Ferrario E, Riva C, Trabattoni D, Ridolfo AL, Villa ML, Shearer GM, Moroni M and Galli M (1996b) Type 1 cytokine production and low prevalence of viral isolation correlate with long term non progression in HIV infection. AIDS Res. Hum. Retrovir. 12: 1053-1061

Cocchi F, De Vico AL, Garzino-Demo A, Arya SK, Gallo RC and Lusso P (1995) Identification of RANTES, MIP-1 alpha, and MIP-1 beta as the major HIV-suppressive factors produced by CD8+ T cells. Science 270: $1811-$ 1815

Cohen IJ, Duke RC, Fadok VA and Sellins KS (1992) Apoptosis and programmed cell death in immunity. Annu. Rev. Immunol. 10: 267-293

Connors M, Kovacs JA, Krevat S, Banacloche-Gea JC, Sneller MC, Flanigan M, Metcalf JA, Walker RE, Faloon J, Baseler M, Stevens R, Feuerstein I, Masur $\mathrm{H}$ and Lane Clifford (1997) HIV infection induces changes in CD4+ T cell phenotype and depletions within the CD4+ T cell repertoire that are not immediately restored by antiviral or immune based therapies. Nature Med. 5: $533-540$

Debatin K-M, Fahrig-Faissner A, Enenkel-Stoodt S, KreuzW, Benner A and Krammer $\mathrm{PH}$ (1994) High expression of Apo-1 (CD95) on T lymphocytes from HIV-infected children. Blood 83: 3101-3103

Dhein J, Walczac H, Baumler C, Debatin K-M and Krammer PH (1995) Autocrine T cell suicide mediated by APO-1 (Fas/CD95). Nature 373: 438-441 
Dolan MJ, Clerici M, Blatt SP, Hendrix CW, Melcher GP, Boswell RN, Freeman TM, Ward W, Hensley R and Shearer GM (1995) In vitro T cell function, delayed type hypersensitivity skin testing, and CD4 T cell subset phenotyping independently predict survival time in patients infected with human immunodeficiency virus. $J$. Infect. Dis. 172: 79-87

Ehret A, Westendorp MO, Herr I, Debatin KM, Heeney JL, Frank R and Krammer PH (1996) Resistance of chimpanzee T cells to human immunodeficiency virus type 1 Tat-enhanced oxidative stress and apoptosis. J. Virol. 70: 6502-6507

Ellis RE, Yuan J and Horvitz HR (1991) Mechanisms and functions of cell death. Annu. Rev. Cell Biol. 7: 663-698

Estaquier J, Idziorek T, De Bels F, Barré-Sinoussi F, Hurtrel B, Aubertin AM, Venet A Mehtali M, Muchmore E, Michel P, Mouton Y, Girard M and Ameisen JC (1994) Programmed cell death and AIDS:significance of T cell apoptosis in pathogenic and nonpathogenic lentiviral infections. Proc. Nat. Acad. Sci. (USA) 91: 9431 9435

Estaquier J, Idziorek T, Zou W, Emilie D, Farber C-M, Bourez J-M and Amiesen J-C (1995) Thelper 1/T helper 2 cytokines and T cell death: preventing effect of IL-12 on activation-induced and CD95 (Fas/Apo-1)-mediated apoptosis of CD4+ T cells from human immunodeficiency virus-infected person. J. Exp. Med. 182: $1759-1767$

Finkel TH, Willim-Tudor G, Banda NK, Cotton MF, Curiel T, Monks C, Baba TW, Ruprecth RM and Kupfer A (1995) Apoptosis occurs predominantly in bystande cells and not in productive cells of HIV- and SIV-infected lymphnodes. Nature Med. 1: 129-134

Fleury-Feith J, Van Nheieu JT, Picard C, Escudier E and Bernaudin JF (1992) Bronchoalveolar lavage eosinophilia associated with pneumocystis carinii pneumonia in AIDS patients. Comparative study with non-AIDS patients. Chest 95: $1198-1201$

Giorgi JV, Fahey JL and Smith DC (1987) Early effects of HIV on CD4 lymphocytes in vivo. J. Immunol. 138: 3725-3730

Golstein P, Ojcius DM and Young JDE (1991) Cell death mechanisms and the immune system. Immunol. Rev. 121: 29-65

Gougeon ML, Olivier S, Garcia D and Montaigner L (1991) Mise en evidence d'un processus d'engagement vers la mort cellulaire par apoptose dans les lymphocytes de patients infecte par le VIH. C R Acad. Sci. Paris. Ser. III Sc. Vie 312: $529-540$

Gougeon ML, Gardia S and Heeney J (1993) Programmed cell death in AIDS-related HIV and SIV infections. AIDS Res. \& Hum. Retrovir. 9: 553-560

Gougeon M-L, Lecoeur H, Dulioust A, Enouf MG, Crouvoisier C, Goujard C, Debord T and Montagnier L (1996) Programmed cell death in PBL from HIV-infected persons: the increased susceptibility to apoptosis of CD4 and CD8 T cells correlates with lymphocyte activation and with disease progression. J. Immunol. 156: $3509-3519$

Gougeon M-L, Lecoeur H, BoudetF, LedruE, Marzabal S, Boullier S, Roue R, Nagata S and Heeney J (1997) Lack of chronic immune activation in HIV infected chimpanzees correlates with the resistance of $T$ cells to Fas/Apo-induced apoptosis and preservation of a T helper 1 phenotype. J. Immunol. 158: 2964 2976

Groux H, Torpier G, Montré D, Mouton Y, Capron A and Ameisen JC (1992) Activation-induced death by apoptosis in CD4+ $T$ cells from human immunodeficiency virus-infected asymptomatic patients. J. Exp. Med. 175: $331-340$

Groux H, Monte D and Plouvier B (1993) CD3-mediated apoptosis of human medullary thymocytes and activated $T$ cells: respective roles of interleukin-1 interleukin-2, interferon gamma, and accessory cells. Eur. J. Immunol. 23 $1623-1630$

Haase A (1996) In: Summary report of the public meeting of the NIH panel to define principles of therapy of HIV infection. Washington, DC November 13-14, 1996 pp 3-5

Heeney J, Jonker R, Koornstra W, Garcia S and Gougeon ML (1993) The resistance of HIV-infected chimpanzees to progression to AIDS correlates with absence of HIV-related T cell dysfunction. J. Med. Primatol. 22: 194200

Ho DD, Neumann AU, Percison AS, Chen W, Leonard JM and Markowitz M (1995) Rapid turnover of plasma virions and CD4 lymphocytes in HIV-1 infection. Nature 373: $123-126$

Israel-Biet D, Labrousse F, Tourani J-M, Sors H, Andrieu JM and Even P (1992) Elevation of IgE in HIV-infected subjects: A marker of poor prognosis. J. All. Clin. Immunol. 89: 68-74
Ito N, Yoncara S, Ishij A, Yoncard M, Mitsushima S, Sameshima M, Hase A, Sato Y and Nagata N (1991) The polypeptide encoded by the cDNA for human cell surface antigen Fas can mediated apoptosis. Cell 75: 1169-1178

Ju S-T, Panka DJ, Cui H, Ettinger R, El-Khatib M, SherrDH, Stunger BZ and MarshakRothstein A (1995) Fas (CD95)/FasL interactions required for programmed cell death after T cell activation. Nature 373: 444-448

Katsikis PD, Wunderlich ES, Smith CA, Herzenberg LA and Herzenberg LA (1995) Fas antigern stimulation induces marked apoptosis of T lymphocytes in human immunodeficiency virus infected individuals. J. Exp. Med. 181: $2029-2036$

Kelleher AD, Carr A, Zaunders J and Cooper DA (1996) Alterations in the immune response of HIV-infected subjects treated with an HIV-specific protease inhibitor ritonavir. J. Infect. Dis. 173: 321-329

Klein SA, Dobmeyer JM, Dobmeyer TS, Pape M, Ottmann OG, Helm EB, Hoelzer D and Rossol R (1997) Demonstration of the Th1/Th2 cytokine shift during the course of HIV infection using cytoplasmatic cytokine detection on single cell level by flow cytometry. AIDS 11: 788-765

Kovacs JA, Baseler M, Dewar R, Vogel S, Davey RT jr, Falloon J, Polis MA, Walker RE, Stevens R, Salzman NP, Metcalf JA, MasurH and Lane HC (1995) Increases in CD4+ T lymphocytes with intermittent courses of interleukin-2 in patients with human immunodeficiency virus infection. A preliminary study. N. Eng. J. Med. 332: $567-575$

Lane HC, Depper JM, Greene WC and Fauci AS (1985) Qualitative analysis of immune function in patients with the acquired immunodeficiency syndrome: evidence for a selective defect in soluble antigens recognition. N. Eng. J. Med. 313: 79-84

Laurent-Crawfors AG, Krust B, Muller S, Riviere Y, Rey-Culle M-A, Bechet JM, Montagnier L and Hovanessian AG (1991) The cytopatic effect of HIV is associated with apoptosis. Virol. 185: 829-839

Levy JA (1993) Pathogenesis of human immunodeficiency virus infection. Microbiol. Rev. 57: 183-289

Levy JA, Mackewicz CE and Barker E (1996) Controlling HIV pathogenesis: the role of the noncytotoxic anti-HIV response of CD8+T cells. Immunol. Today 17:217224

Lucey DR, Zajac RA, Melcher GP and the USAF HIV Study Group (1991) Serum IgE levels in 622 persons with HIV infection: IgE elevation with marked depletion of CD4+ T-cells. AIDS Res. \& Hum. Retrovir. 6: 427-429

Lucey DR, Melchers GP, Hendrix CW etal(1991) The US Air Force HIV study 19851990: immunological analyses, seroconversion and the potential utility of a T helper functional assay to predict change in CD4+ T-cell counts during early stages of HIV infection. J. Infect. Dis. 164: 631-637

McCloskey TW, Oyazu N, Kaplan M, Pahwa S (1995) Expression of the Fas antigen on patients infected with HIV. Cytometry 22: 111-114

Medrano FJ, Leal M, Arienti D, Rey C, Zagliani A, Torres Y, Lissen E and Clerici M (1997) Tumor necrosis factor $\beta$ and soluble APO-1/Fas independently predict progression to AIDS in HIV seropositive patients. J. Inf. Dis. in press

Meyaard L, Otto SA, Jonker RR, Mijnster MJ, Keet RPM and Miedema F (1992) Programmed cell death of T cells in HIV infection. Science 257: $217-219$

Miedema F, Petit AJ and Terpstra FG (1988) Immunological abnormalities in human immunodeficiency virus (HIV)-infected asymptomatic homosexual men. HIV affects the immune system before CD4+ Thelper cell depletion occurs. J. Clin. Invest. 82: 1908-1916

Nagata S and Golstein P (1995) The Fas death factor. Science 257: 1449-1456

Yonehara S, Ishij A and Yoncara M (1989) A cell killing monoclonal antibody (antiFas) to a cell surface antigen co-downregulated with the TNF receptor. J. Exp. Med. 169: $1747-1756$

Naor D (1992) A different outlook at the phenotype-function relationship of T cell subpopulations: fundamental and clinical implications. Clin. Immunol. Immunopathol. 62: 127-132

Nieto MA, Gonzalez A and Lopez-Rivas A (1990) IL-2 protects against anti-CD3induced cell death in human medullary thymocytes. J. Immunol. 145: 1364137

Oyazu N, McCloskey TW, Coronesi M, Chirmule N, Kalyanaraman VS and Pahwa S (1993) Accelerated apoptosis in PBMC from human immunodeficiency infected patients and in CD4 cross-linked PBMC from normal individuals. Blood 82 $3392-3400$

Oyazu N and Pahwa S (1995) Role of apoptosis in HIV disease pathogenesis. J. Clin Immunol. 15: 27-231 
Piazza C, Montani Gilardini MS, Moretti S, Cundari E and Piccolella E (1997) CD4+T cells kill CD8+ T cells via Fas/Fas ligand-mediated apoptosis. J. Immunol. 158: $1503-1506$

Raddrizzani M, Accornero P, Amidei A, Aiello A, Delia D, Kurrle R and Colombo MP (1995) IL-12 inhibits apoptosis induced in a human Th1 clone by gp120/CD4 cross-linking and CD3/TcR activation or by IL-2 deprivation. Cell Immunol. 161: $14-21$

Ransdell F and Fowlkes BJ (1990) Clonal deletion versus clonal energy. The role of thymus in inducing self tolerance. Science 248: $1342-1348$

Seder RA, Grabstein KH, Berzofsky JA and McDyer JF (1995) Cytokine interactions in HIV-infected individuals: roles of II-2, IL-12, and IL-15. J. Exp. Med. 182 1067-1078

Silvestris F, Cafforio P, Frassanito MA, Tucci M, Romito A, Nagata S and Dammacco $F$ (1996) Overexpression of Fas antigen on $T$ cells in advanced HIV-1 infection: differential ligation constantly induces apoptosis. AIDS 10: $131-141$

Sloan EM, Young NS, KumarP, Weichold FF, Sato T and Maciejewski JP (1997) Role of Fas ligand ad receptor in the mechanism of $\mathrm{T}$ cell depletion in acquired immunodeficiency syndrome: effect on CD4+ lymphocyte depletion and human immunodeficiency virus replication. Blood 89: 1357-1363

Smith KJ, Skelton HG, Drabick JJ, McCarthy WF, Ledsky R and Wagner KF (1994) Hypereosinophilia secondary to immunodysregulation in patients with HIV-1 disease. Arch. Dermatol. 130: 119-125

Tanaka M, Suda T, Haze K, Nakamura N, Sato K, Kimura F, Motoyoshi K, Mizuki M, Tagawa S, Ohga S, Hatake K, Drummond AH and Nagata S (1996) Fas ligand in human serum. Nature Med. 2: 317-322

Terai C, Kornbluth RS, Pavia D, Richman DD and Carson DA (1991) Apoptosis as a mechanism of cell death in cultured T lymphoblasts acutely infected with HIV. J. Clin. Invest. 87: 1710-1715
Via CS, Tsokos GC, Stocks NI, Clerici M and Shearer GM (1990) Human in vitro allogeneic responses: demonstration of three pathways of Thelper cell activation J. Immunol. 144: 2524-2528

Vigano' A, Principi N, Villa ML, Riva C, Crupi L, Trabattoni D, Shearer GM and Clerici M (1995) Immunologic characterization of children vertically infected with human immunodeficiency virus, with slow or rapid disease progression. J. Pediatr. 126: 368-374

Walker CM, Moody DJ, Stites DP and Levy JA (1986) CD8+ Lymphocytes can control HIV infection in vitro by suppressing virus replication. Science 234 $1563-1566$

Wei X, Ghosh SK, Taylor ME, Johnson VA, Emini EA, Deutsch P, Lifson JD, Bonhoeffer S, Nowak MA, Hahn BH, Saag MS and Shaw GM (1995) Viral dynamics in human immunodeficiency virus type 1 infection. Nature 373: $117-$ 122

Weiss RA (1993) How does HIV cause AIDS? Science 260: 1273-1279

Zheng L, Fisher G, Miller RE, Peschon J, Lynch DH and Lenardo MJ (1995) Induction of apoptosis in mature T cells by tumor necrosis factor. Nature 377: 348-352

Zinkernagel RM and Hengartner $\mathrm{H}$ (1994) T cell mediated immunopathology versus direct cytolysis: implications for HIV and AIDS. Immunol. Today 15: 262-268

Zou W, Lackner AA, Simon M, Durand-Gasselin I, Glanaud P, Desrosier R and Emilie $D$ (1997) Early cytokine gene expression in lymphnodes of macaques infected with SIV is predictive of disease outcome and vaccine efficacy. J. Virol. 71: $1227-1236$ 